\title{
Rebel without a pause
}

\author{
Robert P. Crease delves into a life of Freeman Dyson, a \\ theoretical physicist who chose a non-conformist path.
}

$\mathrm{F}$ reeman Dyson looks like a wizard. Tall and lanky, he has piercing blue eyes, elfin ears, an aquiline nose and a full head of hair, despite being in his 90th year. From the cover of Phillip Schewe's buoyant biography Maverick Genius, he stares at us with an expression that is half cherub, half imp.

Dyson's career is marked by equally sharp contrasts. He has made significant contributions to technical areas of mathematical physics and quantum electrodynamics but also to speculative fields such as space travel and astrobiology. His writings mix science and poetry. He is not religious, yet won the Templeton Prize for "progress in religion”. He crusades against nuclear weapons, but engages in defence research. And he is known for taking heretical positions on subjects such as extrasensory perception and climate change. Yet his most eccentric facet is that he became an eminent theoretical physicist without having a $\mathrm{PhD}$ - a feat for which Richard Feynman, that other famous nonconformist of physics, much envied him.

"This is a biography," Schewe alerts us, "and not science history." Thus we learn of Dyson's beginnings in the United Kingdom, his early attraction to mathematics and his operations research at Royal Air Force Bomber Command during the Second World War. After the war, Dyson moved to the United States, where he worked first at Cornell University in Ithaca, New York, and then the Institute for Advanced Study in Princeton, New Jersey, along with the likes of Albert Einstein and J. Robert Oppenheimer. We hear of Dyson's work on the TRIGA project to build a foolproof nuclear reactor model, and on the Orion project to design a spacecraft that would boost itself to high speeds by surfing on atomic explosions — and that Dyson intended to be aboard the first flight. We read about his work on neutron bombs; his opposition to the Nuclear-TestBan Treaty (because it would inhibit defence research); the solar-energy collector known as the 'Dyson sphere' once mentioned on Star Trek; and his thought experiments classifying possible extrasolar civilizations.

These episodes are rendered without technical detail, which may frustrate those hop-

$\rightarrow$ NATURE.COM For Freeman Dyson on Enrico Fermi, see: go.nature.com/wqbjau published in Physical Review in 1949, work for which many feel he should have received a Nobel Prize. Schewe describes it as a process that involves rede-

Maverick Genius: The Pioneering Odyssey of Freeman Dyson PHILLIP F. SCHEWE Thomas Dunne Books: 2013. 352 pp. $\$ 27.99$ fining an electron's charge and mass by using the "countervailing blizzard of electromagnetic fields" to neutralize infinities that kept cropping up in theories, making the electron "normal again, fit to participate in atomic society". However, Schewe's decision to pitch his breezy account at the non-scientist is, I think, justifiable, as the story has already been covered by several technical histories of physics, such as Frank Close's The Infinity Puzzle (Oxford Univ. Press, 2011) and Silvan Schweber's QED and the Men Who Made It (Princeton Univ. Press, 1994).

One of the pleasures of Schewe's book is waiting for him to uncork the next flamboyant metaphor. Some are more successful than others. "Like Odysseus, Dyson had been entangled in a great war and afterward

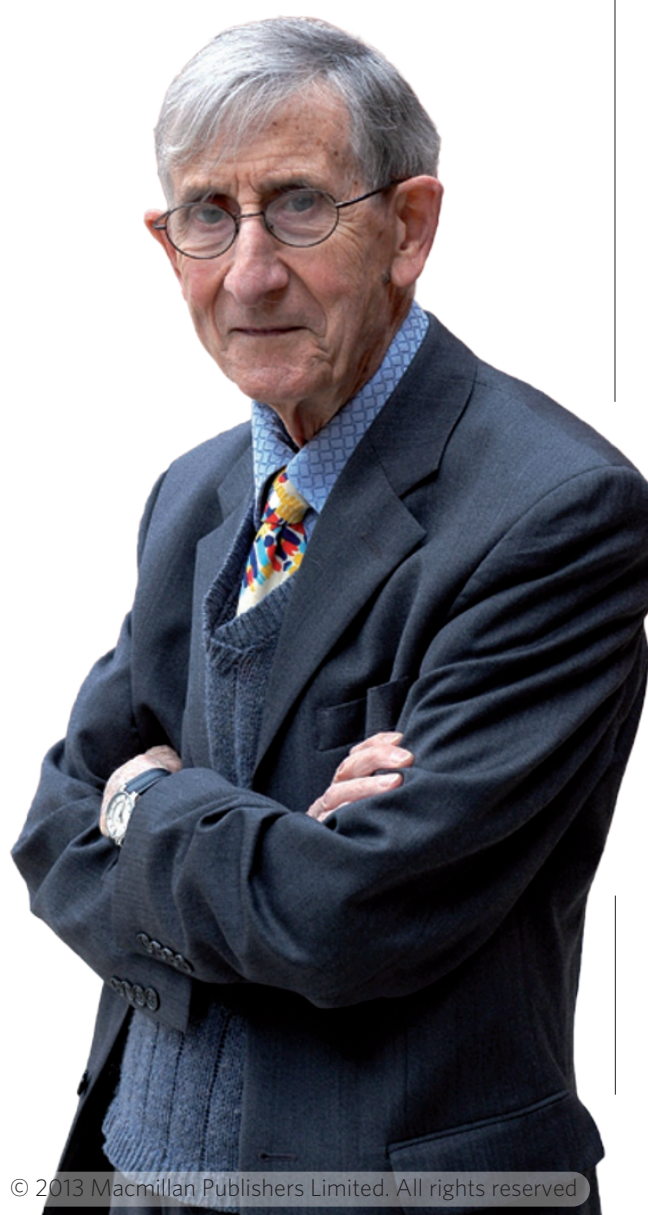

arrived safely in Ithaca," Schewe writes of his subject's migration to Cornell. That made me smile. But comparing Dyson's mugging in Washington DC to Prince Andrei's wounding at the battle of Austerlitz in Tolstoy's War and Peace made me wince. And likening Dyson to the Beatles - and his papers on renormalization to Please Please $\mathrm{Me}$ - is embarrassing.

A few of Schewe's metaphors about other elements of the story also misfire. He compares the twentieth-century physics community to the early Christian church, and calls the initial Shelter Island conference - the first important post-war US gathering of theoretical physicists - an "ecumenical council". The conference was no such thing. Not all key figures attended it, and those who did reviewed and prepared, rather than decreed. It would be more accurate, and equally accessible, to compare the event to a symphony orchestra's pre-performance rehearsal.

Schewe doesn't shy away from the personal, such as who slept with whom in Princeton's intense, tightly knit community. Yet avoiding technical details sometimes inhibits his focus. From today's perspective, was TRIGA safe or risky? Was Orion realistic or foolhardy? Surely the answers matter and reveal aspects of Dyson the man, but Schewe doesn't give us enough information to judge.

In The Scientist as Rebel, one of many articles he has written for the New York Review of Books, Dyson himself writes that "science is a human activity, and the best way to understand it is to understand the individual human beings who practice it". But sometimes an understanding of science is needed to understand the human being who engages in it. This is especially true for someone like Dyson, who uses scientific arguments to defend offbeat positions.

For instance, is Dyson's high-profile, controversial position on climate change — in which he challenges the need to take drastic measures - realistic or reckless? We cannot judge without more discussion of the science of modelling. Discussion of Dyson's opposition to the Superconducting Super Collider and to the Hubble Space Telescope - in his view, oversized enterprises that monopolize resources at the expense of numerous smaller, more worthy projects - would also have brought a sharper, more critical focus on Dyson's contrarian personality, and made the end of Schewe's book read less like an extended, flattering magazine portrait of a prophet. Still, Maverick Genius provides a vivid and enjoyable sketch of one of the most prominent scientific rebels of our day.

Robert P. Crease is professor of philosophy at Stony Brook University, New York 11794, USA, and author of World in the Balance. e-mail: robert.crease@stonybrook.edu 